Instructions for authors, subscriptions and further details:

\title{
http://mcs.hipatiapress.com
}

\section{Mathematics Makes You Feel Attractive. Empowering New Alternative Masculinities in the Context of Mathematics Classroom}

Javier Díez-Palomar ${ }^{1}$ \& Liviu-Catalin Mara²

1) University of Barcelona

2) Rovira i Virgili University

Date of publication: February $21^{\text {st }}, 2020$

Edition period: February 2020 - June 2020

To cite this article: Díez-Palomar, J, Mara, L-C. (2020). Mathematics Makes You Feel Attractive. Empowering New Alternative Masculinities in the Context of Mathematics Classroom. Masculinities and Social Change,9(1), 53-84. doi: 10.17583/MCS.2020.4698

To link this article: http://doi.org/10.17583/MCS.2020.4698

PLEASE SCROLL DOWN FOR ARTICLE

The terms and conditions of use are related to the Open Journal System and to Creative Commons Attribution License (CC-BY). 
pp. 53-84

\title{
Mathematics Makes You Feel Attractive. Empowering New Alternative Masculinities in the Context of Mathematics Classrooms
}

Javier Díez-Palomar

University of Barcelona
Liviu-Catalin Mara

Rovira i Virgili University

\begin{abstract}
This article studies the relationship between masculinity construction in school and mathematics learning in boys. For this purpose, we introduce the variables of social interaction and the differentiation between the language of ethics and the language of desire. The methodology used is a literature review, drawing on discourse analysis as a methodology to identify the relevant themes emerging from the studies analysed. We found several issues that seem to negatively condition mathematics learning in boys that have to do with specific gender identity construction, namely the development of Dominant Traditional Masculinities. Moreover, this negative behavior towards mathematics learning is enhanced by the social attraction towards violence. However, the literature also contains elements that respond to a different model of masculinity that can be successful in mathematics learning and attractive at the same time, which is related to the New Alternative Masculinities model. We conclude with some recommendations to support this new model of attractiveness and masculinity in order to rethink research in mathematics achievement in children in the future in the light of the implications of these different models of masculinity.
\end{abstract}

Keywords: mathematics, New Alternative Masculinities, attractiveness 
MCS - Masculinities and Social Change Vol. 9 No. 1 February 2020

pp. 53-84

\section{Las Matemáticas te Hacen Sentir Atractivo. Empoderando Nuevas Masculinidades Alternativas en el Contexto de las Clases de Matemáticas}

Javier Díez-Palomar

Univeridad de Barcelona
Liviu-Catalin Mara

Universitat Rovira i Virgili

\section{Resumen}

Este artículo estudia la relación entre la construcción de la masculinidad en la escuela y el aprendizaje de las matemáticas en los chicos. Para este propósito, introducimos las variables de la interacción social y la diferenciación entre el lenguaje de la ética y el lenguaje del deseo. La metodología utilizada es una reseña literaria, basándonos en el análisis del discurso como metodología para identificar temas relevantes que surjan de los estudiantes analizados. Encontramos algunos asuntos que parecen condicionar negativamente el aprendizaje de las matemáticas en los chicos que tienen que ver con construcciones de la identidad de género específicas, concretamente con el desarrollo de Masculinidades Tradicionales Dominantes. Además, este comportamiento negativo hacia las matemáticas se ve reforzado por la atracción social hacia la violencia. En cualquier caso, la literatura contiene también elementos que responden a un modelo diferente de masculinidad que puede ser exitoso en el aprendizaje de las matemáticas y atractivo al mismo tiempo, lo cual está relacionado con el modelo de Nuevas Masculinidades Alternativas. Concluimos con algunas recomendaciones para apoyar este modelo de atractivo y masculinidad para reconsiderar la investigación sobre el rendimiento en matemáticas en los niños en el futuro a la luz de las implicaciones de estos modelos de masculinidad.

Palabras clave: matemáticas, Nuevas Masculinidades Alternativas, atractivo

2020 Hipatia Press

ISSN: 2014-3605

DOI: $10.17583 / \mathrm{MCS} .2020 .4698$ 


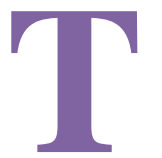

he objective of this article is to discuss whether mathematics learning is connected to masculinity or not, and if so, in which terms, since many times being "good" at mathematics is linked to a social image of being a "nerd" or a non-popular boy within the peer group. Agency, self-identity, desire to be attached to a group of peers, social pressure to play a particular role within the group, attraction and being attractive, are facts that matter especially when boys and girls move from childhood towards adolescence (Simmons, 2017). Teachers working in middle and high schools already know how difficult it is to deal with this type of situations (Brahier, 2016). In addition to the curriculum, they need to work on students' attitudes, emotions, feelings, behavior, which are as important as cognitive aspects of learning. Some authors use the metaphor of the teacher being a "juggler," someone who plays with the fragile balance between the various aspects of teaching (Seckel \& Font, 2020). Previous research suggests that "interaction" has a remarkable impact combining all these elements within the classroom context (Bakker, Smit, \& Wegerif, 2015; Calcagni \& Lago, 2018; Mercer \& Howe, 2012; Racionero \& Padrós, 2010; Villardón-Gallego, García-Carrión, Yañez-Marquina, \& Estévez, 2018). When students' interactions with other peers are based on positive values towards schooling and learning, their readiness to learn is dramatically different than the disposition to learn of students who base their self-identity in values such as "resistance against authority", or "aggressive behavior", linking their position within the peer group to holding such type of values. Interaction based on dialogic principles such as egalitarian dialogue, or the exchange of arguments based on validity claims (Díez-Palomar \& Cabré, 2015; Flecha, 2014), open the opportunity for students to improve their academic achievement. Children holding those "positive" values (towards learning and schooling) engage in respectful, supportive and non-violent behaviors. Racionero and Padrós (2010) claim that children participating in groups where interactions are grounded on those dialogic values learn more and, at the same time, they transform how they value the school, learning, etc. Evidence suggest that children participating in a context where interactions are framed by these types of "positive" interactions, manifest a 
relevant desire to hold the same type of interactions. They want to be part of the group; thus, they appreciate learning, and this is seeing as something "desirable" (Sancho \& Pulido, 2016). However, this is not always the case. Valls, Puigvert, and Duque (2008) report on the opposite case: the "link between attractiveness and violence, grounded in aspects of the hegemonic model of masculinity such as domination, aggressiveness, lack of sensitivity, and power relationships." (p. 768) According to them, for many teenagers the "model man" that they use to define their identity is "what they call a «bastard» or a «macho» or a «show-off»." (p. 768) Evidence suggest that this "negative" model has a lot of prevalence among some teenagers in our current societies. Students endorsing this approach use "violence", and "aggressive behavior", as sources for defining their self-identity within the group, holding a "resistance-against-school" attitude as means of their position within the group of peers. For those students, "being popular" means to resist teachers' authority and show and aggressive behavior toward other students. Thus, in those groups, interactions are framed by such values.

This article is structured in five sections. After the introductory section, in the second section of the article, we discuss the theoretical framework that connects the construction of masculinities models with boys' performance at school. In the third section, we present the data collection and analysis techniques used for the literature review. In the fourth section, we present the results and discussion on the main dimensions identified in the literature, namely gender, masculinity and students' mathematics achievement, construction of the identity, and social attraction towards violence and academic performance. Finally, we present the conclusions of our research.

\section{Theoretical Framework}

\section{Research in Mathematics Education}

Researchers in mathematics education have devoted their attention to scrutinize how individuals learn mathematics. For several years, the main topic of attention was the cognitive development of mathematics 
understanding. The research community was eager to identify children difficulties in learning mathematics (Figueiredo \& de Lourdes Batista, 2018; Morales \& DiNapoli, 2018). Less attention was paid towards adults, which still have been under-researched, in terms of how they (we) learn mathematics (Coben et al., 2003; Hoogland, Díez-Palomar, \& Vliegenhart, 2018, July).

Later, socio-cultural theories gained presence within the researchers' community. Learning mathematics was re-defined also as a social process, not just as a cognitive one. Authors payed attention to the context, the interactions, norms, and a large number of facts affecting how children (and adults) learn mathematics (Alrø, Skovmose, \& Valero, 2003; Bishop, 2013; Carraher, Carraher, \& Schliemann, 1985; Clarke, Keitel, \& Shimizu, 2006; d'Ambrosio, 1985; d'Ambrosio, 2006; De Abreu, 2000; Gelfer \& Organ, 2018; Jurdak, Vithal, De Freitas, Gates, \& Kollosche, 2016; Lerman, 2001, 2006; Nunes, 1999; Radford, 1997; Valero, 2004; Vithal, 2003; Vithal \& Valero, 2003). Researchers and practitioners started to pay attention to those children who resist schooling. Some of them defined this type of situations as a consequence of the capitalistic social structure (Willis, 1977). Deficit theories used SES, and similar social variables, to mislead their research, claiming that schools reproduce the capitalist social order, hence students from disadvantaged social classes or ethnic and cultural minority groups, are undermined within the school system (Bernstein, 2004; Bourdieu, 1986, 1997, 2013; Bowles \& Gintis, 2003; Cole, 1988).

However, less or no attention was paid to how students position themselves within the classroom or in the peer group. Social interaction, which research has revealed as a crucial factor to understand how learning works in social environments (such as a school, a classroom, etc.) (Aubert, Molina, Schubert, \& Vidu, 2017; Calcagni \& Lago, 2018; García-Carrión, 2015; Villardón-Gallego et al., 2018), has been dismissed in the field of mathematics education until recent times (Bakker et al., 2015; Denzin, 2016; Kazak, Wegerif, \& Fujita, 2015; Knuth \& Peressini, 2001; Nordin \& Björklund Boistrup, 2018; Saxe \& Guberman, 1998; Voigt, 2013; Wegerif, 2011). 
The research community in the field of mathematics education keeps in defining their (our) object of study as children having difficulties in learning, or as social structures affecting or conditioning how children learn. But the majority of the researchers have never put the attention to the fact that many children (and teenagers) do not learn mathematics because for them failing in mathematics is a matter of gaining a relevant position within the peer group. Defining them as "troublemakers", as "rebels", or similar names, distracts the focus from those children, teenagers and young adults who already pay attention to the teacher, who manifest solidarity with their peers, engage in productive talk (Díez-Palomar \& Cabré, 2015; García-Carrión \& Díez-Palomar, 2015), and they reject violence and resistance towards schooling as ways of being popular.

\section{Boys Being Boys}

In the mid-1990s, many researchers expressed their concern about boys' underachievement because of "boys being boys" (Foster, Kimmel, \& Skelton, 2001). In 1995-1996 the Center for Research and Education on Gender at the University of London Institute of Education organized a series of seminars titled "Are boys now underachieving?". Participants in that international seminar communicated their worry about the increasing tendency among boys to resist schooling as a way to become "popular" within the group because the majority prefer being part of the lads' group rather than being called ear'oles (Willis, 1977). During the 1990s, there was a feeling of panic toward that situation among teachers, families, and researchers. They were worried because more and more boys were deciding to underachieve because that was a "requirement" to have access to the selected group of "popular boys" in school. That was part of their identity as being boys. For these boys resisting schooling (being bad boys) was the essential thing in life, but such attitude and behavior impregnated and colonized all spaces within the school. In that context of interaction being a boy meant being a tough guy, even if that meant to fail in mathematics [and other school topics], and to receive teachers' punishment (because it was a 
symbol of their resistance and manhood towards their peers). Of course, there was no way for them to join and appreciate their classmates who worked hard on their grades; not even girls, because they were the image of "feminity" (girlish), which was rejected by DTM-boys. Researchers decided to focus their attention on looking for solutions to recover those adolescents and put them in the "right direction" (Epstein, 1998; Martino \& Meyenn, 2001; Moreau, Mendick, \& Epstein, 2009; Watson, 2010). There was a "crusade" to "recover" and "save" those boys from their violent and aggressive behavior. The main idea was to transform classroom practices to engage boys' interests and to work with their perceived strengths to "correct" their violent behavior (Miedzian, 2002). Lingard and Douglas (1999) used the notion of "recuperative masculinity" trying to generate somehow a men's movement, as pointed out by Foster et al. (2001) later on.

\section{Defining the Scope for Masculinity}

Flecha, Puigvert and Ríos (2013) have clarified three different types of masculinities that men can assume. Men may act as Dominant Traditional Masculinities (DTM), Oppressed Traditional Masculinities (OTM), or New Alternative Masculinities (NAM). The main difference between the two former and the one later is the fact that NAM explicitly rejects any form of violence, especially violence against women and publicly positions against it. Unlike DTM or OTM, NAM are self-confident but respectful with others, not grounding their own agency as a violent reaction against others, but as a choice not to exercise any form of violence, nor join with anyone who uses or allows it. As quoted by Soler (2008), NAM-boys are "egalitarian, but they are also conscious of their worth. They gain a lot of respect because they are very conscious that they have a lot of security." Those boys do not use violence (power relationships), but they act based on validity claims (in terms of Habermas, 1984). On the contrary, DTM-boys base their self-identity (and position within the group of peers) in "dominant and violent attitudes and behaviours." (Puigvert, Gelsthorpe, Soler-Gallart, \& Flecha, 2019, p.2). In the same vein, OTM-boys do not reject violence explicitly; as Flecha, 
Puigvert and Ríos (2013) claim, "OTM is complementary to DTM, as are two sides of the same coin." (p. 90). They are those boys "who hold egalitarian values but are considered 'not sexy'." (Puigvert et al., 2019, p.3). This taxonomy has had a significant impact on educational studies (Puigvert et al., 2019; Villarejo-Carballido, Pulido, de Botton, \& Serradell, 2019).

Researchers suggest that there is a social representation (Moscovici, 1984) of "popularity" as "being lad" (Martino \& Meyenn, 2001). For this reason, according to Epstein (1998), many boys tend to construct their own identity drawing on aggressive and violent values, becoming "bad boys," even if this means to resist schooling and underperform in their scores.

Flecha, Puigvert, and Ríos (2013) claim that making the distinction between the language of ethics and the language of desire is crucial in all contexts of social interaction as the type of language used contributes to the development of a particular type of masculinity. For instance, in terms of education, teachers may use the language of ethics when teaching students what is appropriate to do and what is not. However, when some adolescents cheat at solving a test, they know that this is not a correct behavior (language of ethics), but for some of them, cheating may be funny and even a way to reinforce their status in their group of peers (language of desire) (Sierksma, Spaltman, \& Lansu, 2019). In the same vein, adolescents know that they must be "good students," but sometimes it is easier (and more motivating / attractive) for them not to be a "good student," but a "popular boy" (in the group). In fact, some of them choose "aggressive behaviors" as a mean to obtain this position of "popularity" among the rest of the boys in the group. Being a "tough boy", not a "good student", resistant against the teacher' authority, becomes a strategy for them to gain their desired position of "being the popular one" within the group. Ethics points them to one direction, while desire points them to the opposite one. Drawing on Flecha, Puigvert and Ríos' contribution, it seems clear that a discourse based on the language of ethics will not be effective for aggressive students to leave the DTM model and decide to stop acting like "tough boys." They will not automatically change to paying attention in class, respecting their classmates, working hard on the assignments, or doing the homework, etc.; because all these elements 
are not "attractive" for them since it is not connected to what they understand as being popular within their group of peers. Moscovici (1976, 1980, 1984) discussing Asch' (1951) studies about the influence of majorities in a group of people, claimed that minorities, even a few people, may influence the majority of the group (Moscovici, 1976). Probably not all students in the group may defend DTM-boys' behavior publicly when the teacher (or another person) reprimands it. However, what emerges from the literature review is that there is shared compliance among the majority of the students with DTM-boys' behavior because some of them want to hold a position of popularity within the group as those boys do. Adolescents know what the correct way is to do things. However, this seems not to be connected with what [many of them] desire.

\section{Methodology}

In this article, we report on a literature review. According to Hart (2018), a literature review is an essential part of any research process. It is a formal way to underline the state-of-the-art of a particular theme of research. It entails the selection of available documents (both published and unpublished) on the subject, containing information, ideas, data, and evidence framing the contributions already done within a topic, and/or illuminating what the gaps within the research domain on that topic (Hart, 2018) are. This literature review is useful as it aims to inform future research on the topic.

\section{Data collection and analytical instruments.}

Conducting a literature review involves reporting in previous studies using a series of methods to collect and analyse data on a defined topic of study or research question. We may find both qualitative and quantitative strategies, as well as mixed methods. The studies reviewed use interviews, surveys, observation, designed experiments in controlled environments, narratives, biographical research, group discussions, photo and vignette interviews, taskoriented interviews, tests (assessments), group discussions, debriefings, 
memos, self-biographies, ethnographies, peer group and pair work observations, and so forth (Jenner, Flick, von Kardoff, \& Steinke, 2004).

The studies reviewed also use a wide range of analytical tools to analyze the data collected. Among them, discourse analysis (Gee, 2004) is the preferred method used in qualitative studies, along with grounded theory (Glaser \& Strauss, 2017) and ethnographical methods. Several studies also use the communicative methodology (Gómez, Padrós, Ríos-González, CatalinMara, \& Pukepuke, 2019; Gómez, Puigvert, \& Flecha, 2011; Gómez, 2019; Hoogland, Auer, Díez-Palomar, O'Meare, Van Groenestijn, 2019, February).

Regarding quantitative analysis, techniques such as descriptive statistics, structural equation models, and factor analysis, are mainly used.

\section{Managing Evidence in the Reviewed Literature}

In order to collect and select all the studies discussed in this article, we have conducted an extensively review using international databases such as Web of Science (including Journal Citations Reports), and Scopus. We used combinations of keywords to conduct the review (Figure 1).

Mathematics AND learning AND popular boys (WoS+JCR n=4; Scopus n=0)

Mathematics AND attractive AND boys being boys (WoS+JCR $n=1$; Scopus $\mathrm{n}=0$ )

Masculinities AND learning (WoS+JCR n=639; Scopus n=89)

Mathematics AND lad boys (WoS+JCR $n=0$; Scopus $n=0$ )

Mathematics AND attractive (WoS+JCR n=3.651; Scopus n=33)

Mathematics AND popular boys (WoS+JCR $n=16$; Scopus $n=0$ )

Mathematics AND boys being boys (WoS+JCR $n=158$; Scopus $n=0$ ) 
Mathematics AND nerds (WoS+JCR n=6; Scopus n=0)

School failure AND mathematics AND boys being boys (WoS+JCR $n=2$; Scopus $\mathrm{n}=0$ )

School failure AND boys being boys (WoS+JCR $n=86$; Scopus $n=22$ )

School failure AND mathematics (WoS+JCR n=506; Scopus $n=25$ )

School failure AND popular boys (WoS+JCR $n=12$; Scopus $n=0$ )

Academic achievement AND violence AND popular boys (WoS+JCR $n=1$; Scopus $\mathrm{n}=0$ )

Academic achievement AND violence AND boys being boys (WoS+JCR $\mathrm{n}=11 ;$ Scopus $\mathrm{n}=0$ )

Academic achievement AND popular boys (WoS+JCR $n=44$; Scopus $n=0$ )

Academic achievement AND boys being boys (WoS+JCR $n=255$; Scopus $\mathrm{n}=30$ )

Masculinity AND academic achievement AND mathematics AND popular boys $($ WoS +JCR $n=0$; Scopus $n=0)$

Masculinity AND academic achievement AND mathematics AND boys being boys $($ WoS+JCR $n=0$; Scopus $n=0)$

Masculinity AND academic achievement AND popular boys (WoS+JCR $n=7$; Scopus $n=0$ )

Masculinity AND academic achievement AND boys being boys (WoS+JCR $\mathrm{n}=9$; Scopus $\mathrm{n}=2$ )

Masculinity AND popular boys (WoS+JCR $n=113$; Scopus $n=1$ )

Masculinity AND boys being boys (WoS+JCR $n=297$; Scopus $n=154$ )

Figure 1. 
List of keywords and word chains used in the review (WoS, including JCR, and Scopus).

After the search for potential documents (articles), a systematic analysis was conducted to identify relevant contributions in terms of the scope of this literature review. A coding scheme a priori created based on a preliminary analysis of the keywords of the articles identified was used, which was readjusted and re-defined through the whole process of reviewing, constructing the theory along with the topic of study, as in grounded theory (Glaser \& Strauss, 2017). Articles failing to meet the keywords defined within the scope of the review were declined. Generative themes emerged from the review, drawing on the discourse analysis method (Gee, 2004), giving rise to analytical categories aligned to conceptual components. Substantive coding was used to conceptualize the evidence based on the articles reviewed. The initial categories were merged onto the final coding scheme (Table 2). Researchers' memos were sorted within the discussion section.

Table 2.

Final coding scheme and definitions.

\begin{tabular}{ll}
\hline Code & Definition \\
\hline Gender & $\begin{array}{l}\text { Social condition of being male or female } \\
\text { and social values attached to it }\end{array}$ \\
Academic achievement & $\begin{array}{l}\text { Is the extent to which a student has } \\
\text { achieved the educational goals (i.e. } \\
\text { standards within the curriculum) }\end{array}$ \\
Masculinity identity & $\begin{array}{l}\text { Is a set of behaviors, roles, attitudes } \\
\text { socially associated to boys and men }\end{array}$
\end{tabular}


DTM

Table 2.

Final coding scheme and definitions.
OTM

NAM

Violence (including bullying)

Social attraction to violence

Popularity
Men or boys who use aggressivity and violence as the basis for defining their identity
Men or boys who are subdued to DTMmen or DTM-boys. As Flecha, Puigvert and Ríos (2013) claim: "DTM and OTM are two sides of the same coin" (p. 90)

Men or boys who reject any kind of violence and aggressive behavior, drawing on egalitarian interactions to define their identity

Actions that are intended to hurt, use force, impose. Bullying refers to a behavior of a person who hurts or frightens someone smaller or less powerful, forcing that person to do something against their will

Feeling of liking the ones who use / are violence and aggressivity as a characteristic of their identity

The fact that someone is liked, enjoyed or supported by many people 


\begin{tabular}{ll}
\hline Resistance & $\begin{array}{l}\text { The act of fighting against something, or } \\
\text { refusing to accept something }\end{array}$
\end{tabular}

\section{Results and Discussion}

\section{Construction of the Identity}

Violent boys increase their popularity while actively worsening their academic achievement (Epstein, 1988). Previous research has already demonstrated that identity is the result of a social process (Mead, 1934). Being a lad (DTM) or an ear'ole (OTM) depends on how the peer group defines someone. Evidence suggests that social images (Moscovici, 1976) are used as warrants to justify assumptions or stereotypes. In her book, Epstein (1988) narrates the case of a 6-year-old child being interviewed in Panorama (a BBC1 program), who claimed that a boy who works hard at school is "not a boy". Epstein (1998) notice that:

Nevertheless, the extensive evidence of boys being troublesome in schools, does give rise to a gut feeling (yet to be tested by research) that masculinist behaviors, including those which involve avoiding academic work at least up till the sixth form, may have something to do with a relative lack of 'achievement' (however problematic the term) by many boys at GCSE level (Epstein, 1998, p. 97).

It is generally acknowledged that multiple factors influence the construction of the identity. According to Hejazi, Lavasani, Amani, and Was (2012), it is accepted that "success and failure in academic tasks are fundamental building blocks in the development of contemporary youth's identity" (p. 297-298). Was, Al-Harthy, Stack-Oden, and Isaacson (2009) have provided evidence supporting that there is a relationship between students' academic identity status and achievement goals. Students seeing 
themselves as "good students" use to obtain better scores in educational tests and assessments. Recent studies demonstrate that a positive attitude towards learning (based on personal effort, commitment, etc.) correlates even more with success than cognitive skills (Hsin \& Xie, 2014).

Boys adopting aggressive behavior (as DTM boys) gain popularity among the peer group. Garandeau, Ahn, and Rodkin (2011) have examinded 968 fourth and fifth graders from 46 classrooms in 9 schools, and they found a prevalent tendency of aggressive students to use violence to obtain a better position in the peer status hierarchy. Interestingly, they also found that bullies increase their popularity in low-level groups (whereas they are significantly less appreciated in high-performance groups). The research also confirms that the "desire for social success" prevents boys from supporting the victims of bullying (Sutton \& Keogh, 2000). Instead, they prefer either being active bullies or passive followers, which is consistent with the situation described by Flecha, Puigvert and Ríos (2013) using the terms DTM- and OTM-boys, respectively. As they claim, "OTM is complementary to DTM, as are two sides of the same coin." (Flecha, Puigvert, \& Ríos, 2013, p. 90). Aggressivity is consistently used to construct and perform masculinity as a strategy to acquire status within the peer-group (Swain, 2004). However, according to the literature, problematic behaviors negatively predict academic achievement (Malecki \& Elliot, 2002). On the contrary, social skills as the ones handled by NAM-boys may predict academic achievement positively. Evidence also suggests that intervention programs aiming at encouraging positive prosocial behavior among students increase their performance (Caprara et al., 2014; McGrath \& Noble, 2010; McIntosh, Bennett, \& Price, 2011) significantly.

\section{Social Attraction towards Violence and Poor Academic Performance}

There are a few reviews and meta-analysis focused on the consequences of violence in childhood, focusing on educational outcomes (Fry et al., 2018). However, all of them agree on the fact that violence and peer victimization is highly linked to poor academic performance, including side effects such as 
depression, peer rejection, and decreases in students' sense of school belonging. Violence exposition impacts negatively on academic achievement. Drawing on an extensive review, Espelage, Hong, Rao, and Low (2013) conclude that: peer victimization might contribute to poor academic performance in school through mediating influences of internalizing behaviors (DeRosier \& Mercer, 2009; Graham, Bellmore, \& Mize, 2006; Hawker \& Boulton, 2000; Nishina, Juvonen, \& Witkow, 2005; Schwartz et al., 2005). (Espelage et al., 2013, p. 235).

Similarly, Basch (2011) found the same association between exposition to and exhibition of violence (aggressive behaviors) and poor learning performance. According to him, aggressive behaviours "have a negative impact on academic achievement by adversely affecting cognition, school connectedness, and absenteeism" (p. 619). There is much evidence proving that disruptive behavior impedes teaching and learning. Drawing on an extensive study involving 42,000 11- to 17-year-old students, Basch (2011) claims that violence is associated to negative self-consequences (depression, etc.), but also to disruptive behaviors, including bullying, problems with conduct and getting along with others. Similar results have been found in other studies, reviews and meta-analysis (Juvonen, Graham, \& Schuster, 2003; Kochenderfer \& Ladd, 1996; Schwartz \& Gorman, 2003; Youngblade et al., 2007).

Puigvert et al. (2019) have found that there is a social attraction to violence. Using vignettes showing violent and non-violent men, Puigvert and her colleagues (2019) found that teenagers in middle schools associate attractiveness and language of desire towards violent men, whereas nonviolent men are associated to ethical behavior. Popularity among the group of peers is based on this attraction towards violence. Popular boys are the ones who usually present themselves as being tough, aggressive, and bad boys, as reported by Epstein in the late 1990s. Boys "must be" violent if they want to be identified as "boys." In an interview with a teenager described by Epstein in 1999, the girl responds to the interviewer' question about "who gets bullied?" in the following way: 
DE: Uh, who gets bullied? I mean what is there, is there a kind of child that you could say that this child is likely to get bullied?

Ruth: The child who doesn't hit back, um, the child who doesn't interact particularly well, who doesn't have such a lot of social skills, tend to be on their own. The child who's, not necessarily physically small, but sometimes the child who stands out, who doesn't fit in with the crowd, the boy who settles down to work, it tends to be, indeed. (Epstein, 1998, p. 102).

The bad boys must fail at school. The literature consistently supports that claim. Foster and his colleagues (2001) found strong evidence suggesting that disruptive behavior (including disturbing teachers from teaching), and school failure underpin bad boys' strategies to become popular within the group of peers. According to them, "testosterone" is the reason why those kids perform in that way. However, other studies have systematically proved that that behavior is mediated by the social pressure of the group (Basch, 2011; Díez-Palomar, Capllonch, \& Aiello, 2014; Flecha et al., 2013; Puigvert, 2014; Valls et al., 2008). These results suggest that failure in learning mathematics could also be due to the dilemma of "boys being boys," as another typical variable to add to the cases of children failing in learning mathematics, supposedly because of learning difficulties attached to some mathematical concepts, ideas, or relationships. The later type of reasons emerges depending on whether children focus actively on learning mathematics. However, the former reason (attraction towards violence) may explain why some kids fail even before making any effort to learn mathematics.

\section{New Alternative Masculinities and Academic Achievement in Mathematics}

The term NAM is a new contribution to the field of studies on masculinities, that is gaining momentum in our current time (Castro \& Mara, 2014; DíezPalomar, 2016; Díez-Palomar et al., 2014; Flecha et al., 2013; Gómez \& Jiménez, 2018; Redondo, 2016; Rodríguez-Navarro, Ríos-González, 
Racionero, \& Macías, 2014). Flecha and his colleagues (2013) define NAMmen as:

The ones who are being more active working against gender violence together with women. They move away from people with nonegalitarian values or who are violent and seek egalitarian relationships based on desire and love. (p. 102)

The literature available in the field suggests that excellent achievers in mathematics are boys who do not match with the "violent boy" model. Good problem-solvers in mathematics (Piñeiro, Castro, \& Castro-Rodríguez, 2016; Schoenfeld, 2016; Shulman, 1986) are normally students who share some (or all) of the psychological and social skills matching with NAM boys, as defined by Flecha et al. (2013). Guinjoan Francisco et al. (2015) claim that students sharing NAM-boys' values are highly outperforming in mathematics problem-solving; they are exceedingly confident in making conjectures and intuition (in Fischbein' terms). Students who are highly outperforming in mathematics show self-confidence in decision-making, a conviction for their own choices, they are not influenced by the decisions of others without critical examination. Instead, they prefer to verify for themselves the validity and truthfulness of answers when some alternative solutions are provided in the task. This attitude appears aligned to other aspects, such as motivation and expertise, as well as mental agility (Liljedahl, Santos-Triguero, Malaspina, \& Bruder, 2016). Successful problem-solvers do not resist either schooling or learning mathematics; instead, they are highly motivated. A positive attitude towards mathematics appears to be also associated to other psychological factors as their ability to intuitively reduce a problem to its essentials, to reverse their line of thought, to minding several aspects of the problem at the same time, to be ready to change their own assumptions in order to find the correct solution, and to be able to transfer their expertise to other situations (Liljedahl, Santos-Trigo, Malaspina, \& Bruder, 2016, p. 4-5).

According to previous research, success in learning mathematics depends (or it is associated) to what Skemp (1976) named as "relational understanding" and "instrumental understanding" 1 . Later studies have moved 
forward from Skemp's (1976) approach, but still highlight the association of learning with understanding (Ball \& Bass, 2003; Carpenter \& Lehrer, 1999; Erlwanger, 1973; Hiebert \& Carpender, 1992; Schoenfeld, 2016, Stylianides \& Stylianides, 2007).

Learning mathematics depends on the individuals' ability to verbalize and justify the mathematical concepts that they are working with. Drawing on that evidence, it would be suitable to conjecture that having a space where individuals feel "free" to share their own claims would (potentially) encourage mathematical understanding and learning. Those spaces must be free of violence and disruptive behaviors, otherwise participants would be exposed first to an aggressive environment, which would compromise their opportunity to learn mathematics effectively. However, this is a new line of research, and there is not much literature on that topic. Díez-Palomar and Cabré (2015) narrate the case of using "interactive groups" to encourage students to use validity claims to justify their claims within the context of small collaborative (dialogic) problem-solving tasks. They found that boys who focus on the task, looking to share their answers with the rest of the group, generate "dialogic spaces for learning" in which the interaction is mediated by validity arguments, rather than by power claims (usually based on aggressive or disruptive ways to show agency). Boys characterized as "bad-boys" within the group, showed fewer levels of participation within the process of solving the tasks. Their source for "popularity" in the group of peers as being "bad boys" (DTM-boys) was not valued within the interactive groups, where active participants were working to solve the problem. On the contrary, boys presenting potential answers to the task, and sharing with their peers their arguments to justify those possible answers, gained a protagonist role within the group.

\section{Conclusion}

There is a plethora of research suggesting what are the ways to design meaningful and successful tasks in mathematics (Ainley \& Pratt, 2005), what are the best strategies for different (diverse) students to solve problems (De 
Corte, Verschaffel, \& Greer, 2000), how these strategies match with different approaches to mathematical reasoning development (Carpenter \& Lehrer, 1999; Hiebert \& Carpenter, 1992), how to introduce the aspects of race, class and gender to open mathematics learning to all children (Gates \& Jorgensen, 2009), etc. All these aspects are essential when the kid decides that he wants to study [mathematics].

However, little attention has been paid to the fact that learning mathematics is a social process mediated by interactions in which participants play a crucial role, especially in terms of their willingness to learn, the position that they want to occupy within the group of peers, and how the basis for popularity are distributed among the members of that group of peers. If failure and poor performance are linked to violence, allocating resources to redress the deficits of those violent boys, this fact is useless to transform either the context of attraction towards violence or the popularity of the social image of the bad boy (malote, in Spanish) who fails at school.

On the contrary, "having a positive attitude towards learning mathematics" depends on the link between the language of ethics and the language of desire around schooling, and zero attraction towards violence. The literature review suggests that when desire and ethics are on different sides, the work that we do from research in mathematics education to find ways to overcome cognitive difficulties that exist around certain concepts or mathematical structures (number, number sense, percentages, and fractions, problem-solving, etc.) stumbles against an impenetrable wall. We cannot teach mathematics, nor improve school results in tests of competence such as the PISA tests, etc. if adolescents do not see mathematics as something important and attractive. Hence, teachers' educational decisions must be oriented towards implementing those actions that have proved to be successful in suppressing the distance between the language of ethics and the language of desire (Flecha, 2014), empowering NAM-boys rather than looking for remedial solutions for DTM-boys.

\section{Aknowledgements}


The first author wants to acknowledge the support of the Spanish Ministerio de Ciencia, Innovación y Universidades through the grant PEX19/00547.

\section{Notes}

'Skemp defines these concepts as: “distinguishes by calling them 'relational understanding' and 'instrumental understanding'. By the former is meant what I have always meant by understanding, and probably most readers of this article: knowing both what to do and why. Instrumental understanding, I would until recently not have regarded as understanding at all. It is what I have in the past described as 'rules without reasons', without realising that for many pupils and their teachers the possession of such a rule, and ability to use it, was why they meant by 'understanding'." (Skemp, 1976, p.89).

\section{References}

Ainley, C. J., \& Pratt, D. (2005, July). RF01: The Significance of Task Design in Mathematics Education: Examples from Proportional Reasoning. In Chick, H. L., \& Vincent, J. L. (Eds.), Proceedings of the $29^{\text {th }}$ Conference of the International Group for the Psychology of Mathematics Education, 1, (pp. 93-122). Melbourne: PME. Alrø, H., Skovsmose, O., \& Valero, P. (2003, February-March). Communication, conflict and mathematics education in the multicultural classroom. In M. A. Mariotti (Ed.), European Research in Mathematics Education III: Proceedings of the Third Conference of the European Society for Research in Mathematics Education, 3, (pp. 1-6). Bellaria, Italy: University of Pisa en ERME.

Asch, S. E. (1951). Effects of group pressure upon the modification and distortion of judgments. In H. Guetzhow (Ed.), Groups, leadership, and men, (pp. 295-303). Pittsburgh, PA: Carnegie Press.

Aubert, A., Molina, S., Schubert, T., \& Vidu, A. (2017). Learning and inclusivity via Interactive Groups in early childhood education and care in the Hope school, Spain. Learning, Culture and Social Interaction, 13, 90-103. doi: 10.1016/j.lcsi.2017.03.002

Bakker, A., Smit, J. \& Wegerif, R. (2015). Scaffolding and dialogic teaching in mathematics education: Introduction and review. ZDM, 47(7), 10471065. doi: 10.1007/s11858-015-0738-8 
Ball, D. L., \& Bass, H. (2003). A Research Companion to Principles and Standards for School Mathematics. In J. Kilkpatrick, G. Martin, \& D. Schifter (Eds.), A research companion to principles and standards for school mathematics (pp. 27-44). Reston, VA: National Council of Teachers of Mathematics.

Basch, C. E. (2011). Agression and violence and the achievement gap among urban minority youth. Journal of School Health, 81(10), 619-625. doi: 10.1111/j.1746-1561.2011.00636.x

Bernstein, B. (2004). The structuring of pedagogic discourse. London: Routledge.

Bishop, A. (2013). Mathematics education and culture. New York: Springer. Bourdieu, P. (1986). Habitus, code et codification. Actes de La Recherche En Sciences Sociales, 64(1), 40-44. doi: 10.3406/arss.1986.2335

Bourdieu, P. (1997). Capital cultural, escuela y espacio social. Madrid: Siglo XXI.

Bourdieu, P. (2013). Distinction: A social critique of the judgement of taste. New York: Routledge.

Bowles, S., \& Gintis, H. (2003). Schooling in capitalist America twenty-five years later. Sociological Forum, 18(2), 343-348. Retrieved from https://www.jstor.org/stable/3648906

Brahier, D. J. (2016). Teaching secondary and middle school mathematics. New York and London: Routledge.

Calcagni, E., \& Lago, L. (2018). The three domains for dialogue. A framework for analysing dialogic approaches to teaching and learning. Learning, Culture and Social Interaction, 18, 1-12. doi:

10.1016/j.lcsi.2018.03.001

Caprara, G. V., Kanacri, B. P. L., Gerbino, M, Zuffiano, A. Alessandri, G., Vecchio, G. M., Caprara, E., Pastorelli, C., \& Bridglall, B. (2014).

Positive effects of promoting prosocial behavior in early adolescence. Evidence from a school-based intervention. International Journal of Behavioral Development, 38(4), 386-396. doi:

10.1177\%2F0165025414531464

Carpenter, T. P., \& Lehrer, R. (1999). Teaching and learning mathematic with understanding. In E. Fennema \& T. A. Romberg (Eds.), 
Mathematics classrooms that promote understanding (pp. 19-32). London and New York: Routledge.

Carraher, T. N., Carraher, D. W., \& Schliemann, A. D. (1985). Mathematics in the streets and in schools. British Journal of Developmental Psychology, 3(1), 21-29. doi: 10.1111/j.2044-835X.1985.tb00951.x

Castro, M., \& Mara, L. C. (2014). The social nature of attractiveness: how to shift attraction from the dominant traditional to alternative masculinities. International and Multidisciplinary Journal of Social Sciences, 3(2), 182-206. doi: 10.4471/rimcis.2014.36

Civil, M., Díez-Palomar, J., Menéndez, J. M., \& Acosta-Iriqui, J. (2008). Parents' Interactions with Thier Children When Doing Mathematics. Adults Learning Mathematics, 3(n2a), 41-58.

Clarke, D., Keitel, C., \& Shimizu, Y. (2006). Mathematics classrooms in twelve countries: The insider's perspectives. Rotterdam and Taipei: Sense publishers.

Coben, D., Colwell, D., Macrae, S., Boaler, J., Brown, M., \& Rhodes, V. (2003). Adult numeracy: Review of research and related literature. London: National Research and Development Centre for adult literacy and numeracy.

Cole, M. (1988). Contradictions in the educational theory of Gintis and Bowles. In M. Cole (Ed.), Bowles and Gintis Revisited. Correspondence and contradiction in educational theory (pp. 16-32). London and New York: Routledge.

d'Ambrosio, U. (1985). Ethnomathematics and its place in the history and pedagogy of mathematics. For the Learning of Mathematics, 5(1), 44-48. Retrieved from https://www.jstor.org/stable/40247876

d'Ambrosio, U. (2006). Ethnomathematics: Link between traditions and modernity. Rotterdam and Taipei: Sense publishers.

De Abreu, G. (2000). Relationships between macro and micro socio-cultural contexts: Implications for the study of interactions in the mathematics classroom. Educational Studies in Mathematics, 41(1), 1-29. doi: 10.1023/A:1003875728720

De Corte, E., Verschaffel, L., \& Greer, B. (2000, November). Connecting mathematics problem solving to the real world. In Proceedings of the 
International Conference on Mathematics Education into the $21^{\text {st }}$

Century: Mathematics for living (pp. 66-73).

Denzin, N. K. (2016). Critical Qualitative Inquiry. Qualitative Inquiry, 23(1), 8-16. doi: 10.17583/mcs.2016.2351

Díez-Palomar, J. (2016). Men, Masculinities and Teaching in Early

Childhood Education. Masculinities \& Social Change, 5(3), 321-322.

doi: $10.17583 / \mathrm{mcs} .2016 .2351$

Díez-Palomar, J., \& Cabré, J. (2015). Using dialogic talk to teach

mathematics: The case of interactive groups. ZDM, 47(7), 1299-1312.

doi: 10.1007/s11858-015-0728-x

Díez-Palomar, J., Capllonch, M., \& Aiello, E. (2014). Analyzing Male

Attractiveness Models From a Communicative Approach: Socialization,

Attraction, and Gender-Based Violence. Qualitative Inquiry, 20(7), 844849. doi: 10.1177/1077800414537205

Díez-Palomar, J., Garcia-Wehrle, P., Molina, S., \& Rue, L. (2010).

Aprendizaje dialógico en las matemáticas y en las ciencias. Revista

Interuniversitaria de Formación Del Profesorado, 24(1), 75-88.

Epstein, D. (1998). Failing boys?: Issues in gender and achievement.

McGraw-Hill Education (UK).

Erlwanger, S. H. (1973). Benny's conception of rules and answers in IPI

mathematics. Journal of Children's Mathematical Behavior, 1(2), 7-26.

Espelage, D. L., Hong, J. S., Rao, M. A., \& Low, S. (2013). Associations

between peer victimization and academic performance. Theory into

Practice, 52(4), 233-240. doi: 10.1080/00405841.2013.829724

Figueiredo, H. R. S., \& de Lourdes Batista, I. (2018). Mathematics History

and Cognitive Values on a Didactic Sequence: Teaching Trigonometry. REDIMAT. Journal of Research in Mathematics Education, 7(3), 311332. doi: 10.17583/redimat.2018.2727

Flecha, R. (2014). Succesful educational actions for inclusion and social cohesion in Europe. Cham: Springer.

Flecha, R., Puigvert, L., \& Ríos, O. (2013). The New Alternative

Masculinities and the overcoming of gender violence. International and Multidisciplinary Journal of Social Sciences, 2(1), 88-113. Retrieved from 
https://hipatiapress.com/hpjournals/index.php/rimcis/article/view/612 Foster, V., Kimmel, M., \& Skelton, C. (2001). What about the boys? An overview of the debates. In W. Martino \& B. Meyenn (Eds.), What about the Boys? Issues of Masculinity in Schools (pp. 1-23). Buckingham: Open University Press.

Fry, D., Fang, X., Elliott, S., Casey, T., Zheng, X., Li, J., Florian, L., McCluskey, G. (2018). The relationships between violence in childhood and educational outcomes: a global systematic review and meta-analysis. Child Abuse \& Neglect, 75, 6-28. doi: 10.1016/j.chiabu.2017.06.021 Garandeau, C. F., Ahn, H.-J., \& Rodkin, P. C. (2011). The social status of aggressive students across contexts: The role of classroom status hierarchy, academic achievement, and grade. Developmental Psychology, 47(6), 1699. doi: 10.1037/a0025271

García-Carrión, R. (2015). What the dialogic literary gatherings did for me:

The personal narrative of an 11-year-old boy in a rural community in England. Qualitative Inquiry, 21(10), 913-919. doi:

$10.1177 \%$ 2F1077800415614305

Garcia-Carrion, R., \& Díez-Palomar, J. (2015). Learning communities: Pathways for educational success and social transformation through interactive groups in mathematics. European Educational Research Journal, 14(2), 151-166. doi: 10.1177/1474904115571793

Gates, P., \& Jorgensen, R. (2009). Foregrounding social justice in mathematics teacher education. Journal of Mathematics Teacher Education, 12(3), 161-170. doi: 10.1007/s10857-009-9105-4 Gee, J. P. (2004). An introduction to discourse analysis: Theory and method. New York: Routledge.

Gelfer, J., \& Organ, J. (2018). Quantum Masculinities: Doing Gender with Max Tegmark's Mathematical Universe Hypothesis. Masculinities \& Social Change, 7(3), 213-229. doi: 10.17583/mcs.2018.3470 Glaser, B. G., \& Strauss, A. L. (2017). Discovery of grounded theory: Strategies for qualitative research. New York: Routledge.

Gómez, A., \& Jiménez, J. M. (2018). Radical Love: Remembering Freire, Joe, and Pato. International Review of Qualitative Research, 11(1), 6-10. doi: 10.1525/irqr.2018.11.1.6 
Gómez, A., Padrós, M., Ríos-Gonzalez, O., Catalin-Mara, L., \& Pukepuke,

T. (2019). Reaching Social Impact through the Communicative

Methodology. Researching With Rather than On Vulnerable Populations: the Roma Case. Frontiers in Education, 4(9), 1-8. doi:

10.3389/feduc. 2019.00009

Gómez, A., Puigvert, L., \& Flecha, R. (2011). Critical communicative methodology: Informing real social transformation through research. Qualitative Inquiry, 17(3), 235-245. doi:

$10.1177 \% 2 F 1077800410397802$

Gómez, A. (2019). Science With and for Society Through Qualitative Inquiry. Qualitative Inquiry, online first. doi:

10.1177/1077800419863006

Guinjoan, M., Fortuny, J. M., \& Gutiérrez, Á. (2015). Análisis del comportamiento de alumnos expertos resolutores de problemas en el contexto del concurso matemático Pruebas Canguro. Enseñanza de Las Ciencias, 33(1), 29-46. doi: 10.5565/rev/ensciencias. 1438

Habermas, J. (1984). The Theory of Communicative Action. Reason and the Rationalization of Society. Boston, MA.: Beacon Press.

Hart, C. (2018). Doing a Literature Review: Releasing the Research Imagination. New York: Sage.

Hejazi, E., Lavasani, M. G., Amani, H., \& Was, C. A. (2012). Academic Identity Status, Goal Orientation, and Academic Achievement among High School Students. Journal of Research in Education, 22(1), 291320. Retrieved from https://files.eric.ed.gov/fulltext/EJ1098413.pdf

Hiebert, J., \& Carpenter, T. P. (1992). Learning and teaching with understanding. In D. A. Grouws (Ed.), Handbook of research on mathematics teaching and learning (pp. 65-97). Reston, VA: National Council of Teachers of Mathematics.

Hoogland, K.; Auer, M.; Díez-Palomar, J.; O’Meara, N.; Van Groenestijn, M. (2019, February). Initiating a common european numeracy framework. In CERME Proceedings. Utrecht: ERME.

Hoogland, K., Díez-Palomar, J., \& Vliegenthart, M. (2018, July). Towards a common european numeracy framework for adults. In B. Kelly, D. Kaye, G. Griffiths, D. Dalby, J. Evans, \& J. Stacey (Eds.), Boundaries and 
bridges: Adults learning mathematics in a fractured world. Proceedings of the 25th Adults Learning Mathematics international conference - A research forum (pp. 64-67). London: ALM.

Hsin, A., \& Xie, Y. (2014). Explaining Asian Americans' academic advantage over whites. Proceedings of the National Academy of Sciences, 111(23), 8416-8421. doi: 10.1073/pnas.1406402111

Jenner, B., Flick, U., von Kardoff, E., \& Steinke, I. (2004). A companion to qualitative research. New York: Sage.

Jurdak, M., Vithal, R., De Freitas, E., Gates, P., \& Kollosche, D. (2016). Social and political dimensions of mathematics education: Current thinking. Cham: Springer.

Juvonen, J., Graham, S., \& Schuster, M. A. (2003). Bullying among young adolescents: The strong, the weak, and the troubled. Pediatrics, 112(6), 1231-1237. Retrieved from

https://pediatrics.aappublications.org/content/112/6/1231

Kazak, S., Wegerif, R., \& Fujita, T. (2015). The importance of dialogic processes to conceptual development in mathematics. Educational Studies in Mathematics, 90(2), 105-120. doi:

https://doi.org/10.1007/s10649-015-9618-y

Knuth, E., \& Peressini, D. (2001). Unpacking the nature of discourse in mathematics classrooms. Mathematics Teaching in the Middle School, 6(5), 320. Retrieved from https://eric.ed.gov/?id=EJ658176

Kochenderfer, B. J., \& Ladd, G. W. (1996). Peer victimization: Cause or consequence of school maladjustment? Child Development, 67(4), 13051317. doi: https://doi.org/10.2307/1131701

Lerman, S. (2001). Cultural, discursive psychology: A sociocultural approach to studying the teaching and learning of mathematics. Educational Studies in Mathematics, 46(1-3), 87-113. doi: https://doi.org/10.1023/A:1014031004832

Lerman, S. (2006). Socio-cultural research in PME. In A. Gutiérrez \& P. Boero (Eds.), Handbook of research on the psychology of mathematics education (pp. 347-366). Rotterdam and Taipei: Brill Sense.

Liljedahl, P., Santos-Trigo, M., Malaspina, U., \& Bruder, R. (2016). Problem solving in mathematics education. In Problem Solving in 
80 Díez-Palomar \& Mara-Mathematics Makes You Feel Attractive

Mathematics Education (pp. 1-39). Cham: Springer.

Lingard, B., \& Douglas, P. (1999). Men engaging feminisms pro-feminism, backlashes and schooling. Buckingham: Open University Press.

Malecki, C. K., \& Elliot, S. N. (2002). Children's social behaviors as predictors of academic achievement: A longitudinal analysis. School Psychology Quarterly, 17(1), 1. doi: 10.1521/scpq.17.1.1.19902

Martino, W., \& Meyenn, B. (2001). What about the boys?: Issues of masculinity in schools. Buckingham: Open University Press.

McGrath, H., \& Noble, T. (2010). Supporting positive pupil relationships: Research to practice. Educational and Child Psychology, 27(1), 79. Retrieved from https://psycnet.apa.org/record/2010-10870-007

McIntosh, K., Bennett, J. L., \& Price, K. (2011). Evaluation of social and academic effects of school-wide positive behaviour support in a Canadian school district. Exceptionality Education International, 21(1), 46-60. Retrieved from https://ir.lib.uwo.ca/eei/vol21/iss1/5/

Mead, G. H. (1934). Mind, self and society. Chicago: Chicago University Press.

Mercer, N., \& Howe, C. (2012). Explaining the dialogic processes of teaching and learning: The value and potential of sociocultural theory. Learning, Culture and Social Interaction, 1(1), 12-21. doi:

https://doi.org/10.1016/j.lcsi.2012.03.001

Miedzian, M. (2002). Boys will be boys: Breaking the link between masculinity and violence. New York: Lantern Books.

Morales, H., \& DiNapoli, J. (2018). Latinx Bilingual Students' Perseverance on a Mathematical Task: A Rehumanizing Perspective. REDIMAT. Journal of Research in Mathematics Education, 7(3), 226-250. doi: 10.17583/redimat.2018.3274

Moreau, M.-P., Mendick, H., \& Epstein, D. (2009). Constructions of mathematical masculinities in popular culture. In E. Watson (Ed.), Pimps, wimps, studs, thugs and gentlemen: Essays on media images of masculinity (pp. 141-156). Jefferson, NC: McFarland Publishers Jefferson, NC.

Moscovici, S. (1976). Social influence and social change. New York: Academic Press. 
Moscovici, S. (1980). Toward a theory of conversion behavior. In L.

Berkowitz (Ed.), Advances in experimental social psychology (pp. 209239). New York: Academic Press.

Moscovici, S. (1984). The phenomenon of social representations. In R. M.

Farr \& S. Moscovici (Eds.), Social representations (pp. 3-69).

Cambridge, UK: Cambridge University Press.

Munter, C., Stein, M. K., \& Smith, M. A. (2015). Dialogic and Direct

Instruction: Two Distinct Models of Mathematics Instruction and the

Debate (s) Surrounding Them. Teachers College Record, 117(11), 1-32.

Retrieved from https://eric.ed.gov/?id=EJ1075980

Nordin, A. K., \& Björklund Boistrup, L. (2018). A framework for

identifying mathematical arguments as supported claims created in dayto-day classroom interactions. Journal of Mathematical Behavior, 51, 15-27. doi: 10.1016/j.jmathb.2018.06.005

Nunes, T. (1999). Mathematics learning as the socialization of the mind. Mind, Culture, and Activity, 6(1), 33-52. doi:

10.1080/10749039909524712

Piñeiro, J. L., Castro, E., \& Castro-Rodríguez, E. (2016). Conocimiento profesional para la enseñanza de la resolución de problemas en primaria: una perspectiva curricular. In A. Berciano, C. Fernandez, T. Fernandez, J. Gonzalez, P. Hernandez, A. Jimenez, ... M. Sanchez (Eds.), Investigación en Educación Matemática XX (pp. 427-436). Malaga: Universidad de Málaga.

Puigvert, L. (2014). Preventive socialization of gender violence: Moving forward using the communicative methodology of research. Qualitative Inquiry, 20(7), 839-843. doi: 10.1177\%2F1077800414537221

Puigvert, L., Gelsthorpe, L., Soler-Gallart, M., \& Flecha, R. (2019). Girls' perceptions of boys with violent attitudes and behaviours, and of sexual attraction. Palgrave Communications, 5(1), 56. doi: 10.1057/s41599-0190262-5

Racionero, S., \& Padrós, M. (2010). The dialogic turn in educational psychology. Revista de Psicodidáctica/Journal of Psychodidactics, 15(2), 143-163. Retrieved from https://www.ehu.eus/ojs/index.php/psicodidactica/article/view/808 
Radford, L. (1997). On psychology, historical epistemology and the teaching of mathematics: Towards a socio-cultural history of mathematics. For the Learning of Mathematics, 17, 26-33. Retrieved from https://www.jstor.org/stable/40248219

Redondo, G. (2016). Dialogic leadership and new alternative masculinities: Emerging synergies for social transformation. Masculinities \& Social Change, 5(1), 70-91. doi: 10.17583/mcs.2016.1929

Rodríguez-Navarro, H., Ríos-González, O., Racionero, S., \& Macías, F. (2014). New methodological insights into communicative acts that promote new alternative masculinities. Qualitative Inquiry, 20(7), 870875. doi: $10.1177 \% 2 F 1077800414537209$

Sancho, E., \& Pulido, C. (2016). El club de Valientes de la Comunidad de aprendizaje CP Sansomendi P. Revista Padres y Maestros, 367, 38-41. Saxe, G. B., \& Guberman, S. R. (1998). Studying mathematics learning in collective activity. Learning and Instruction, 8(6), 489-501. doi:

10.1016/S0959-4752(98)00037-1

Schoenfeld, A. H. (2016). Learning to think mathematically: Problem solving, metacognition, and sense making in mathematics (Reprint). Journal of Education, 196(2), 1-38. doi: 10.1177/002205741619600202

Schwartz, D., \& Gorman, A. H. (2003). Community violence exposure and children's academic functioning. Journal of Educational Psychology, 95(1), 163. doi: 10.1037/0022-0663.95.1.163

Seckel, M. J., \& Font, V. (2020). Competencia reflexiva en formadores del profesorado de matemática. Magis, Revista Internacional de Investigación En Educación, 12(25), 127-144. doi:

10.11144/Javeriana.m12-25.crfp

Shulman, L. S. (1986). Those who understand: Knowledge growth in teaching. Educational Researcher, 15(2), 4-14. doi: 10.3102\%2F0013189X015002004

Sierksma, J., Spaltman, M., \& Lansu, T. A. M. (2019). Children tell more prosocial lies in favor of in-group than out-group peers. Developmental Psychology, 55(7), 1428-1439. doi: 10.1037/dev0000721

Simmons, R. G. (2017). Moving into adolescence: The impact of pubertal change and school context. Routledge. 
Skemp, R. R. (1976). Relational understanding and instrumental understanding. Mathematics Teaching, 77(1), 20-26. Retrieved from http://www.davidtall.com/skemp/pdfs/instrumental-relational.pdf

Soler, M. (2008). Impacto de los actos comunicativos y nuevas masculinidades [Impact of communicative acts and new masculinities](RTD Project). Madrid.

Stylianides, A. J., \& Stylianides, G. J. (2007). Learning mathematics with understanding: A critical consideration of the learning principle in the principles and standards for school mathematics. The Mathematics Enthusiast, 4(1), 103-114. Retrieved from https://scholarworks.umt.edu/tme/vol4/iss1/8/

Sutton, J., \& Keogh, E. (2000). Social competition in school: Relationships with bullying, Machiavellianism and personality. British Journal of Educational Psychology, 70(3), 443-456. doi:

10.1348/000709900158227

Swain, J. (2004). The resources and strategies that 10-11-year-old boys use to construct masculinities in the school setting. British Educational Research Journal, 30(1), 167-185. doi: 10.1080/01411920310001630017 Valero, P. (2004). Socio-political perspectives on mathematics education. In B. Atweh (Ed.), Researching the socio-political dimensions of mathematics education (pp. 5-23). Cham: Springer.

Valls, R., Puigvert, L., \& Duque, E. (2008). Gender violence among teenagers: Socialization and prevention. Violence against Women, 14(7), 759-785. doi: 10.1177\%2F1077801208320365

Villardón-Gallego, L., García-Carrión, R., Yáñez-Marquina, L., \& Estévez, A. (2018). Impact of the interactive learning environments in children's prosocial behavior. Sustainability (Switzerland), 10(2138), 1-12. doi:

10.3390/su10072138

Villarejo-Carballido, B., Pulido, C. M., de Botton, L., \& Serradell, O. (2019). Dialogic model of prevention and resolution of conflicts: Evidence of the success of cyberbullying prevention in a primary school in Catalonia. International Journal of Environmental Research and Public Health, 16(6), 918. doi: 10.3390/ijerph16060918 Vithal, R. (2003). Teachers andstreet children': On becoming a teacher of 
mathematics. Journal of Mathematics Teacher Education, 6(2), 165-183. doi: 10.1023/A:1023960111901

Vithal, R., \& Valero, P. (2003). Researching mathematics education in situations of social and political conflict. In A. Bishop, M. Clements, C. Keitel, J. Kilpatrick, \& K.-S. Leung (Eds.), Second international handbook of mathematics education (pp. 545-591). New York: Springer.

Voigt, J. (2013). Negotiation of mathematical meaning in classroom processes: Social interaction and learning mathematics. In L. P. Steffe, P. Nesher, P. Cobb, B. Sriraman, \& B. Greer (Eds.), Theories of mathematical learning (pp. 33-62). New York: Routledge.

Was, C. A., Al-Harthy, I., Stack-Oden, M., \& Isaacson, R. M. (2009). Academic identity status and the relationship to achievement goal orientation. Electronic Journal of Research in Educational Psychology, 7(2), 627-652. doi: 10.25115/ejrep.v7i18.1363

Watson, E. (2010). Pimps, wimps, studs, thugs and gentlemen: Essays on media images of masculinity. Jefferson, NC: McFarland \& Company, Inc., Publishers.

Wegerif, R. (2011). Towards a dialogic theory of how children learn to think. Thinking Skills and Creativity, 6(3), 179-190. doi:

10.1016/j.tsc.2011.08.002

Willis, P. (1977). Learning to labour: How working class kids get working class jobs. New York and London: Routledge.

Youngblade, L. M., Theokas, C., Schulenberg, J., Curry, L., Huang, I.-C., \& Novak, M. (2007). Risk and promotive factors in families, schools, and communities: A contextual model of positive youth development in adolescence. Pediatrics, 119 (Supplement 1), S47-S53. doi: 10.1542/peds.2006-2089H

Javier Díez-Palomar is professor in the Department of Linguistic and Literary Education, and Teaching and Learning of Experimental Sciences and Mathematics, Spain.

Liviu-Catalin Mara is postdoctoral researcher in the Department of Business Management at the Rovira i Virgili University, Spain.

Contact Address: Direct correspondence to Javier Díez-Palomar, Facultat d'Educació, Passeig Vall d'Hebron, 171, 08035 Barcelona, Spain, email: jdiezpalomar@ub.edu 